\title{
PENINGKATAN KEMAMPUAN MATEMATIKA DASAR MELALUI MUSIC AND MOVEMENT
}

\author{
Amna N. Noho \\ Program Studi PGSD, Universitas Muhammadiyah Gorontalo \\ e-mail: amnanoho@gmail.com
}

\begin{abstract}
The purpose of this study was to determine whether the basic math skill students 56 years old can be improved through music and movement. This research was conducted at TKIT Ibnu Sina Duren Sawit, East Jakarta Timur, with as many as 27 students study subjects. The study was conducted in two cycles and accompanied by 2 teachers who act as observers, method action research. Data collected through observation and interviews as well as qualitative and quantitative data analysis. Qualitative data were analyzed by comparing the students' grades in cycle 1 and cycle 2 while the qualitative data was analized by data reduction, display data, and conclusion. The results showed an increase in students' basic math skill through music and movement. In cycle 2 the development of the mathematical aspects of general intelligence has increased 23\% from the initial conditions before the study, in wich each indicator increased by 52\% compared to the time of observation. Based on data analysis, it can be concluded that the students' basic math skill can be improved through music and movement. It is thus suggested to kindergarten teachers to use music and movement in order to improve the learning basic math skill of students.
\end{abstract}

Keywords: Math; Music; Movement

\begin{abstract}
Abstrak
Tujuan penelitian ini adalah mengetahui apakah kemampuan dasar matematika siswa usia 5-6 tahun dapat ditingkatkan melalui kegiatan music and movement . Penelitian ini dilakukan di TKIT Ibnu Sina Duren Sawit, Jakarta Timur, dengan sebanyak 27 siswa subjek penelitian. Penelitian dilakukan dalam dua siklus dan didampingi oleh 2 orang guru yang bertindak sebagai pengamat, metode penelitian
\end{abstract}


tindakan. Data dikumpulkan melalui observasi dan wawancara serta analisis data kualitatif dan kuantitatif. Data kuantitatif dianalisis dengan membandingkan nilai siswa dalam siklus 1 dan siklus 2 sedangkan data kualitatif dianalisis dengan reduksi data, data tampilan, dan kesimpulan. Hasilanya menunjukkan peningkatan kemampuan matematika dasar siswa melalui kegiatan music and movement. Pada siklus 2 perkembangan aspek matematika dasar telah meningkat $23 \%$ dari kondisi awal sebelum penelitian, yang mana setiap indikator meningkat sebesar $52 \%$ dibandingkan dengan waktu pengamatan. Berdasarkan analisis data, dapat disimpulkan bahwa kemampuan matematika dasar siswa dapat ditingkatkan melalui kegiatan music and movement. dengan demikian disarankan kepada guru TK untuk menggunakan music and movement dalam rangka meningkatkan kemampuan matematika dasar siswa.

Keywords: Matematika; Musik; Gerakan

\section{PENDAHULUAN}

Latar belakang penelitian ini menggambarkan bahwa pondasi awal seseorang dalam memperoleh pendidikan dalam upaya mengembangkan potensi yang dimilikinya dimulai dari anak usia dini. Anak usia dini berada pada tahap pertumbuhan dan perkembangan yang paling pesat, baik fisik maupun mental. Jadi tepatlah bila dikatakan bahwa anak usia dini adalah usia emas (golden age), dimana anak berpotensi mempelajari banyak hal dengan cepat.

Pada dasarnya setiap anak dianugerahi kemampuan dasar matematika sebagai kemampuan penalaran ilmiah, perhitungan secara matematis, berpikir logis, penalaran induktif/deduktif, dan ketajaman polapola abstrak serta hubunganhubungan. Dapat diartikan juga sebagai kemampuan menyelesaikan masalah yang berkaitan dengan kebutuhan matematika sebagai solusinya.

Salah satu bentuk kegiatan pengembangan untuk anak usia dini adalah mengembangkan kemampuan matematika permulaan yakni kemampuan berhitung. Kegiatan berhitung dijumpai dimana-mana. Begitu dekatnya kegiatan berhitung dengan kehidupan, membuat program pengembangan kemampuan matematika permulaan untuk anak usia dini menjadi tantangan tersendiri. 
Belajar matematika pada dasarnya adalah belajar berpikir atau belajar memecahkan masalah. Menurut Dodge dan Colker (2000:49) matematika adalah kemampuan untuk menciptakan hubungan-hubungan. Dan untuk menjadi pemikir matematika anak-anak perlu diberi kebebasan untuk menyelidiki, mengorganisasikan benda-benda konkret sebelum mereka dapat menggunaka simbol-simbol yang telah dikenalnya secara abstrak

$$
\text { Jamaris mengungkapkan }
$$

(2006:18) Mengajarkan matematika pada anak tidak sama dengan orang dewasa. Ada sejumlah pembatasan kemampuan dalam memecahkan masalah. Hal ini disebabkan anak bersifat egosentris yaitu cara berpikir benar atau tidak benar, setuju atau tidak setuju berdasarkan sudut pandangan sendiri

Menikmati musik sama halnya dengan mengikuti narasi sejarah kehidupan manusia. Hal ini serupa dengan yang diungkapkan oleh Monty (2002:11) yang mengatakan bahwa "musik adalah saksi kehidupan manusia dan menikmati musik sama halnya dengan mengikuti sejarah kehidupan manusia. Begitu pula dengan menyelami musik, ini sama halnya dengan menyelami kehidupan manusia dan belajar tentang musik sama halnya dengan belajar tentang kehidupan manusia.

Musik merupakan bahasa emosi yang bersifat universal, pendapat ini ditunjang oleh Jamalus (1998 : 64) yang mengatakan bahwa "seni musik adalah bahasa emosi yang bersifat universal.

Fatur mengungkapkan (2010:147) Movement yang berarti gerakan berasal dari kata dasar gerak. Gerak sendiri memiliki makna, yaitu suatu peralihan tempat. Adanya aktivitas yang dilakukan setelah ada dorongan batin dan perasaan juga disebut dengan gerak. Aktivitas gerakan dapat timbul setelah seseorang mendengarkan lagu atu nyanyian. Berdasarkan pengertian tersebut di atas maka menggunakan istilah "gerak dan lagu" adalah untuk mengartikan Music and Movement" lebih jelas

Music and Movement memegang peranan penting dalam proses menumbuh-kembangkan seorang anak. Musik dapat memperkaya kehidupan ruhani dan memberikan keseimbangan hidup bagi anak. Melalui musik, manusia dapat mengungkapkan pikiran dan perasaan hatinya serta dapat mengendalikan emosinya.

Kegiatan music and movement dalam penelitian ini adalah suatu 
kegiatan yang mendorong siswa untuk melakukan kegiatan pembelajaran matematika dengan menciptakan suasana yang menyenangkan dari mulai mengamati, mengungkapkan ide dan perasannya, sampai siswa berpartisipasi aktif.

Bernyanyi dapat dijadikan salah satu alternatif pembelajaran yang menyenangkan bagi anak usia dini. Selain murah meriah dapat dilakukan secara bersama-sama, kelompok kecil, ataupun individu. Saat mulai belajar musik sama dengan saat mulai belajar apa saja. Musik adalah wadah segala pembelajaran di PAUD.

Musik juga merupakan perwujudan atau manifestasi dari kehidupan cipta, rasa, dan karsa seseorang dalam bentuk suara dan irama yang memuaskan. Di dalam seni musik, suara merupakan hal yang penting. Karena keberhasilan cipta seni musik terletak pada vocal disamping irama, melodi, syair dan instrument. Seni musik merupakan bahasa emosi yang universal, dan musik juga dapat membangkitkan respons manusia. Jika seni musik diterpakan dalam pelajaran sekolah, maka seni musik dapat membuat para siswa lebih pintar, membantu otak berfokus pada hal lain yang dipelajari, kemudian pendidikan kesenian penting diajarkan mulai dari anak usia dini, agar peserta didik sejak dini memperoleh stimulasi yang seimbang antara belahan otak kiri dan belahan otak kanannya sehingga dapat berfokus pada hal lain yang dipelajari, serta musik merupakan rangkaian bunyi ekspresif yang disusun dengan maksud membangkitkan respons manusia. Dan musik memang memiliki fungsi atau peran yang sangat penting sehingga tidak satu pun manusia yang bisa lepas dari keberadaan musik.

Dengan demikian musik yang dilakukan dengan cara yang benar dapat meningkatkan kemampuan gerak karena musik mampu merangsang gerak, sebaliknya pula, gerakanpun menghasilkan bunyi, selain itu dapat meningkatkan kemampuan mengingat dan kemampuan berbahasa, serta membantu meningkatkan berbagai kecerdasan, antara lain kecerdasan berfikir logis dan berfikir matematis.

Kegiatan dengan mengikuti irama lagu pada anak usia 5-6 tahun memiliki arti bahwa anak sudah menyadari bahwa gerak irama sebagai suatu instrument dalam melakukan kegiatan khusus. Gerakan pada saat anak melakukan kegiatan bermusik ini merupakan suatu pengalaman yang sangat memacu sensasi-sensasi yang diterima tubuh 
dalam aktifitasnya, sehingga menimbulkan rasa senang. Rasa senang melalui musik dan gerak merupakan puncak kecerdasan seorang anak, sehingga saat inilah pemberian stimulasi atau konsepkonsep diberikan sehingga kegiatan satu kesatuan yang utuh ini memiliki kebermaknaan.

\section{METODE PENELITIAN}

Penelitian ini bertujuan untuk menelaah dan mengambarkan menggunaan music and movement dalam meningkatkan kemampuan matematika dasar anak. penelitian ini dilaksanakan di TKIT Ibnu Sina Duren Sawit Jakarta Timur, dengan subjek penelitian anak di kelas $B$ yang berjumlah 27 orang anak.

Metode yang digunakan dalam penelitian ini adalah penelitian tindakan atau action research yang dikembangkan oleh Kemmis dan Taggart. Penelitian tindakan ini terdiri dari dua siklus dengan masing-masing siklus pertama enam kali tindakan dan siklus kedua tiga kali tindakan. Setiap siklus terdiri dari perencanaan, tindakan, pengamatan dan refleksi.

\section{HASIL PENELITIAN DAN} PEMBAHASAN

Berdasarkan hasil wawancara dan catatan lapangan dan yang dilaksanakan di Kelompok B TKIT Ibnu Sina anak usia 5-6 tahun menunjukkan bahwa dari 27 orang anak yang ada, jika dilihat berdasarkan aspek kemampuan berhitung yang terdiri dari beberapa indikator penilaian yaitu: membilang/menyebut urutan bilangan dari 1 sampai 20, (2) menyebutkan hasil penambahan, (3) menyebutkan hasil pengurangan dengan benda sampai 10 , maka dapat dikatakan bahwa ada 4 orang anak yang belum muncul atau $16 \%, 10$ orang anak yang mulai muncul atau $40 \%, 8$ orang anak yang berkembang sesuai harapan atau $32 \%$ dan 3 orang anak yang sudah berkembang sangat baik atau $12 \%$.

Berdasarkan observasi yang dilakukan maka hasil pelaksanaan tindakan siklus I pada aspek kemampuan berhitung adalah sebagai berikut: (1) anak yang belum masih berjumlah 2 orang atau $8 \%$, (2) anak yang mulai muncul berjumlah 3 orang atau $12 \%$, (3) anak yang berkembang sesuai harapan berjumlah 13 orang atau $52 \%$ dan (4) anak yang sudah berkembang sangat baik berjumlah 7 orang atau $28 \%$. Jika dilihat dari persentase ini maka untuk aspek kemampuan berhitung, anak Kelompok B TKIT Ibnu Sina 
mengalami peningkatan yang signifikan.

Peningkatan pada aspek kemampuan melakukan pengurutan berdasarkan hasil observasi yang dilakukan peneliti bekerjasama dengan kolaborator, adalah sebagai berikut: (1) anak yang belum muncul masih berjumlah 2 orang anak atau $8 \%$, (2) anak yang mulai muncul berjumlah 4 orang anak atau 16\%, anak yang berkembang sesuai harapan berjumlah 15 orang anak atau $60 \%$, dan (4) anak yang berkembang sangat baik berjumlah 4 orang anak atau $16 \%$. Berdasarkan data ini maka untuk aspek kemampuan melakukan pengurutan mengalami peningkatan.

Pada aspek geometri terjadi perubahan sebagai berikut: (1) masih terdapat satu orang anak yang belum muncul atau $4 \%$, (2) anak yang mulai muncul masih berjumlah 4 orang anak atau $16 \%$, (3) anak yang berkembang sesuai harapan berjumlah 12 orang anak atau $48 \%$, (4) berkembang sangat baik berjumlah 6 orang anak atau $24 \%$. Sehingga dapat dikatakan kemampuan matematika anak pada aspek geometri megalami peningkatan.

Berdasarkan hasil observasi paada siklus I dengan enam kali pertemuan yang dilakukan maka dapat disimpulkan bahwa dari ke tiga aspek yang dinilai baik aspek berani,aspek kemampuan berhitung, kemampuan mengurutkan dan kemampuan mengenal bentuk geometri mengalami peningkatan.

Data di atas menunjukkan bahwa terjadi peningkatan pada aspek kemampuan berhitung, kemampuan mengurutkan dan kemampuan mengenal bentuk geometri. Jumlah anak yang belum muncul dan mulai muncul semakin berkurang dan anak yang berkembang sesuai harapan semakin meningkat. Peningkatan yang terjadi sangat baik. selama tindakan dilaksanakan peneliti melakukan pengamatan terhadap kemampuan anak selama kegiatan berlangsung. Peningkatan yang dicapai pada siklus I belum sesuai dengan kreteria keberhasilan yang telah disepakati antara peneliti dan kolaborator yaitu $20 \%$ dari masing-masing aspek yang akan ditingkatkan.

Setelah pelaksanaan siklus II maka peningkatan yang terjadi pada aspek kemampuan berhitung berdasarkan hasil observasi yang dilakukan peneliti bersama dengan kolaborator, adalah sebagai berikut: (1) tidak terdapat lagi anak yang belum muncul atau 0\%, (2) anak yang mulai muncul masih berjumlah 4 
orang anak atau 16\%, (3) anak yang berkembang sesuai harapan meningkat menjadi 14 orang anak atau 52\%, dan (4) anak yang berkembang sangat baik meningkat menjadi 7 orang anak atau $28 \%$. Berdasarkan data ini maka untuk aspek kemampuan berhitung mengalami peningkatan.

Peningkatan yang terjadi pada aspek kemampuan mengurutkan setelah pelaksanaan siklus II adalah sebagai berikut: (1) tidak terdapat lagi anak yang belum muncul atau $0 \%$, (2) anak yang mulai muncul masih berjumlah 2 orang atau $8 \%$, (3) anak yang berkembang sesuai harapan berkurang menjadi 8 orang atau $32 \%$ dan (4) anak yang sudah berkembang sangat baik meningkat jumlahnya menjadi 15 orang anak atau $60 \%$. Sehingga dapat dikatakan bahwa kemampuan matematika dasar anak pada aspek kemampuan mengurutkan mengalami peningkatan yang signifikan dan sesuai dengan harapan yang diinginkan.

Data hasil pelaksanaan tindakan siklus II pada aspek geometri adalah sebagai berikut: (1) tidak terdapat lagi anak yang belum muncul atau $0 \%$, (2) tidak terdapat lagi anak yang mulai muncul atau $0 \%$, (3) terjadi peningkatan pada aspek ini yaitu menjadi 18 orang anak atau $72 \%$, dan (4) anak yang berkembang sangat baik meningkat menjadi 7 orang anak atau $28 \%$. Jika dilihat dari persentase ini maka untuk aspek geometri pada siklus ini untuk anak Kelompok B TKIT Ibnu Sina mengalami peningkatan yang signifikan.

Berdasarkan data hasil observasi pada siklus II dengan tiga kali pertemuan yang dilakukan, maka dapat disimpulkan bahwa dari ke tiga aspek yang dinilai baik aspek berhitung, aspek kemampuan mengurutkan dan aspek geometri mengalami peningkatan. Ketercapain ini berdasarkan kriteria keberhasilan tindakan yaitu $20 \%$ per aspek peranak. Keberhasilan ini sangat ditentukan oleh peneliti dan kolaborator pada saat siklus yang dimulai dengan tahap perencanaan, pelaksanaan, observasi dan refleksi. Kerjasama yang baik sangat menunjang keberhasilan tindakan. Kontribusi terlihat tidak hanya pada kecerdasan matematika (kognitif), tetapi pada seluruh aspek perkembangan yang ada pada anak usia dini (bahasa, fisik, social, afeksi, estetika).

Dari data yang telah dikumpulkan dapat disimpulkan bahwa terjadi peningkatan kemampuan matematika dasar anak 
usia 5 sampai 6 Tahun Kelompok B TKIT Ibnu Sina melalui kegiatan music and movement yang telah diberikan. Hasil peningkatan kemampuan matematika dasar anak Kelompok B TKIT Ibnu Sina selama pelaksanaan tindakan dilaksanakan sejak observasi awal hingga pelaksanaan siklus ke II.

Analisis data dalam penelitian ini menggunakan analisis data kuantitatif dan kualitatif. Analisis data kuantitatif diperoleh yaitu peningkatan kemampuan berhitung, kemampuan mengurutkan dan kemampuan mengenal bentuk geometri dari praintervensi sampai siklus II 23\%. Hasil ini melebihi kesepakatan antara peneliti dan kolaborator, yaitu sebesar $20 \%$. Berdasarkan peningkatan persentase tersebut, maka dinyatakan hipotesis tindakan dapat diterima. Analisis data kualitatif menggunakan model analisis interaktif dari Miles dan Huberman dengan langkahlangkahnya : (1) reduksi data, (2) display data, dan (3) verifikasi atau kesimpulan dari hasil catatan lapangan, catatan wawancara, dan catatan dokumentasi selama penelitian.

\section{Pembahasan}

Kemampuan matematika seringkali dikelompokkan dalam kemampuan kognitif, sebab matematika merupakan kemampuan seseorang dalam menghubungkan berbagai informasi yang ditangkap oleh panca indra dan lingkungannya yang kemudian diproses menjadi sebuah konsep di dalam otak.

Selanjutnya

Piaget menyebutkan bahwa perkembangan dan konsep matematika tahap praoperasional adalah, Anak pada tahap praoperasional ini mampu memanipulasi simbol-simbol atau representasi dunia fisik. Selama priode ini, anak belajar mengkonsevasi, yang digunakan untuk pemahaman matematika permulaan. Anak mengembangkan pemahaman bahwa bahan-bahan atau objek-objek tetap sama walaupun mereka merubah bentuk atau ditata secara berbeda dalam suatu ruang. Bila anak tidak menggunakan abilitasnya untuk mengkonservasi, maka anak tetap mampu belajar keterampilan matematika yang sederhana atau perhitungan rutin, tetapi mereka akan kesulitan dalam mengembangkan pemahaman matematika dan tidak mampu memecahkan masalahmasalah yang lebih kompleks.

Piaget membagi tiga level konservasi :1) Anak melakukan secara alami menempatkan atau memasukkan suatu benda sesuai dengan bentuk 
wadahnya; 2) Anak mengembangkan ide bahwa jumlah bahan tetap sama, bahkan jika di tata secara berbeda atau bertukar posisi; 3) Anak mampu mengkonservasi kuantitas, volume, kuantitas yang tidak sinambung, dan massa. Mereka akan berkata "Ini masih sama, kamu hanya memindahmindahkan saja" atau "Kamu tidak mengambil atau menambah apapun, kamu hanya menempatkannya lebih rapat satu sama lain".

Pengetahuan fisik dan kemampuan matematika saling bergantung dan dapat berkembang secara terus menerus. Karakteristik benda dipelajari, logika matematika dibangun untuk mengorganisasikan informasi. Sebagai contoh pada Goldilocks and Three Bears, papa beruang besar, mama beruang berukuran agak besar (sedang) dan anak beruang yang terkecil (seriasi atau urutan), namun ketiganya (bilangan) adalah beruang karena ditutupi bulu, memiliki bentuk tertentu dengan kombinasi wajah sebagai beruang (klasifikasi).

Kegiatan melalui musik ini mengacu pada pendapat Froebel bahwa kurikulum dan pemberian materi dirancang meliputi pekerjaan atau kegiatan seni, keahlian, pembangunan atau konstruksi. Berdasarkan hal tersebut maka proses pembelajaran diberikan dengan cara bermain dan bernyanyi sebagai kendaraan bagi perkembangan anak untuk meningkatkan kemampuan matematika dasar anak. Belajar matematika pada dasarnya adalah belajar berpikir atau belajar memecahkan masalah.

Mengajarkan matematika pada anak tidak sama dengan orang dewasa. Ada sejumlah pembatasan kemampuan dalam memecahkan masalah. Hal ini disebabkan anak bersifat egosentris yaitu cara berpikir benar atau tidak benar, setuju atau tidak setuju berdasarkan sudut pandangan sendiri. Oleh sebab itu anak belum dapat meletakkan cara pandangnya di sudut pandang orang lain. Gejala egoesntris ini disebabkan oleh masih terbatasnya conservation (konservasi/pengekalan), yakni operasi kognitif yang berhubungan dengan pemahaman anak terhadap aspek dimensi kuantitatif materi lingkungan yang ia respon.

Musik sangat berpengaruh pada perkembangan respons manusia, hal tersebut diungkapkan pula oleh Crist and Delone yaitu "musik merupakan rangkaian bunyi ekspresif yang disusun dengan maksud membangkitkan respons manusia." 


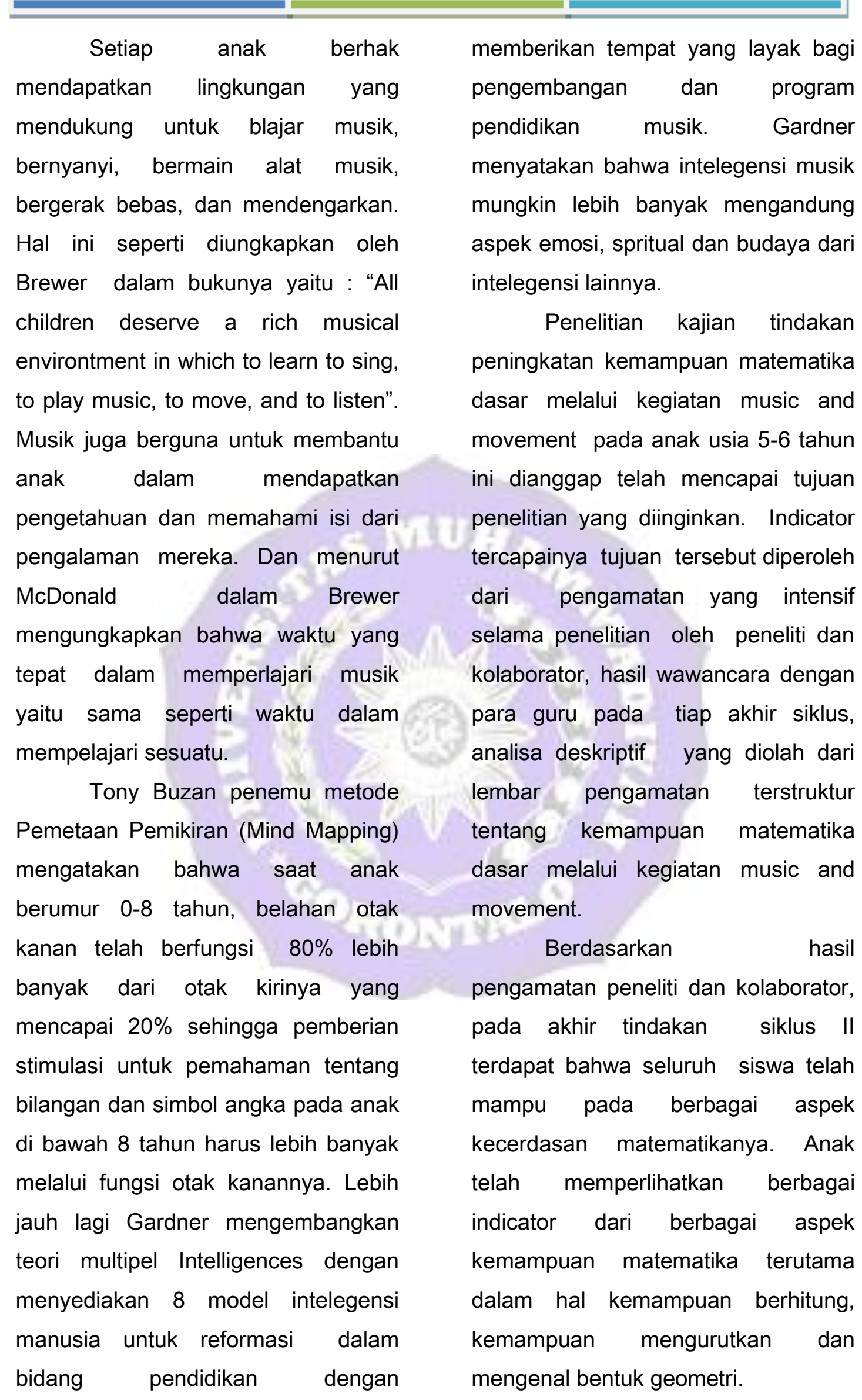


Keberhasilan meningkatkan kemampuan matematika dasar dikarenakan kegiatan bermusik dan gerak merupakan kegiatan alami dan naluri anak usia 5-6 tahun. Kegiatan ini memacu sensasi-sensasi yang diterima tubuh dalam aktifitasnya, sehingga menimbulkan rasa senang. Rasa senang melalui music and movement merupakan puncak kecerdasan seorang anak, sehingga saat inilah pemberian stimulasi kemampuan berhitung dan kemampuan mengurutkan serta geometri diberikan melalui tahapantahapan kegiatan yang menjadi satu kesatuan dan memiliki kebermaknaan.

Keberhasilan ini dapat dilihat dari data kualitataif yang di peroleh peneliti melalui hasil observasi penelitian instrument tindakan, catatan lapangan dan wawancara dengan guru kelas B. Peningkatan hasil belajar ini karena adanya proses pembelajaran berhitung, mengurutkan dan geometri melalui musik dan gerak memperngaruhi emosi anak. Anak merasa senang saat belajar bernyanyi dan adanya persaingan yang kompetitif saat bermain game menjadikan pemberian materi ini mudah di cerna oleh anak.

\section{PENUTUP}

\section{Simpulan}

Hasil penelitian menunjukkan bahwa melalui kegiatan music and movement dapat meningkatkan kemampuan berhitung, mengurutkan dan geometri anak. anak juga dapat belajar dengan cara yang menyenangkan sekaligus dapat meningkatkan kemampuan yang dimiliki berdasarkan potensinya masing-masing.

Implikasi dari penelitian ini adalah bagi pengembangan keilmuan di program studi pendidikan anak usia dini, terutama dalam pengembangan keilmuan mengenai cara meningkatkan kecerdasan logika matematika. Selain itu, hasil dari penelitian ini dapat memberikan kontribusi maupun sumbangan keilmuan tentang strategi permainan pada anak usia dini melalui kegiatan music and movement .

Secara praktis anak usia dini secara alamiah telah menunjukkan ketertarikan terhadap musik dan dalam banyak proses kognitif hal ini akan menunjang proses pemahaman serta perkembangan prilakunya. Sehingga saat inilah puncak kreatifitas dan penanaman konsep-konsep pengembangan pada anak bisa dilakukan. Selain itu, bagi lembaga PAUD, penelitian ini dapat bermanfaat dalam rangka meningkatkan kecerdasan matematika anak dalam 
rangka merancang kegiatan

pembelajaran yang menyenangkan

dan menghindari kegiatan yang

bersifat akademik.

Saran

Hasil penelitian ini dapat

diterapkan lagi meskipun penelitian telah berakhir. Guru dapat terus menerus melakukan perbaikan dan peningkatan hasil belajar anak dengan memperhatikan prosedur dan pedoman yang berlaku. Guru juga dapat mencoba melakasanakan stimulasi matematika secara fleksibel, mudah, menyenangkan dan memberi manfaat bagi anak.

\section{DAFTAR PUSTAKA}

Monty P. Setiadarma, Terapi Musik, (Jakarta : Milenia Populer, 2002), P.11

Dodge and Cholker, The Creative Curriculum for Early Childhood (Washinton, DC, 2000), p. 49

Jamaris Martini, Perkembangan dan

Pengembangan Anak Usia

Taman Kanak-kanak ( Jakarta,

UNJ Press, 2004), p. 18

Jamalus, Pengajaran Musik Melalui

Pagelaran Musik, (Jakarta: P2

LPTK dan University, 1998), p.

64.

Fatur R, Cerdaskan Anakmu dengan

Musik, (Jogyakarta : Diva Press, 2010) h. 147. 